\title{
Analyzing Changes in Motivational Constructs for First-Year Engineering Students during the Revision of a First-Year Curriculum
}

\section{Miss Lilianny Virguez, Virginia Tech}

Lilianny Virguez is a Ph.D. candidate in Engineering Education at Virginia Tech. She has work experience in engineering and has taught engineering courses at the first-year level.Her research interests include motivation to succeed in engineering with a focus on first-year students.

\section{Dr. Kenneth Reid, Virginia Tech}

Kenneth Reid is the Assistant Department Head for Undergraduate Programs in Engineering Education at Virginia Tech. He is active in engineering within K-12, serving on the TSA Board of Directors. He and his coauthors were awarded the William Elgin Wickenden award for 2014, recognizing the best paper in the Journal of Engineering Education. He was awarded an IEEE-USA Professional Achievement Award in 2013 for designing the nation's first B.S. degree in Engineering Education. He was named NETI Faculty Fellow for 2013-2014, and the Herbert F. Alter Chair of Engineering (Ohio Northern University) in 2010. His research interests include success in first-year engineering, engineering in K-12, introducing entrepreneurship into engineering, and international service and engineering. He has written two texts in Digital Electronics, including the text used by Project Lead the Way.

\section{Prof. Tamara Knott, Virginia Tech}

Tamara Knott is Associate Professor of engineering education at Virginia Tech. She is the Director of the First-year Program. Her interests include assessment and pedagogy. Within ASEE, she is a member of the First-year Programs Division, the Women in Engineering Division, the Educational Research and Methods Division, and the Design in Engineering Education Division. She is also a member of the Society of Women Engineers (SWE) and is the Faculty Adviser for SWE at VT. 


\title{
Analysis of Changes in Motivational Constructs for First-Year Engineering Students during the Revision of a First-Year Curriculum
}

\begin{abstract}
The purpose of this research paper is to investigate the changes in motivational constructs for First-Year engineering students based on the revision of one of the introductory courses in the first year program in a large, public university. The course was revised as part of the assessment of the first year curriculum, with specific goals that include more effectively supporting student motivation to enhance student retention. Two versions of the course, classic and revised, were offered during one semester to students within the same cohort. A survey was implemented at the beginning and at the end of the semester in both courses including four constructs of motivation: identity, utility, belonging, and expectancy, along with other questions to collect demographic and course specific data. We analyzed data during the first and second semester when the revised version of the course was offered. During the first semester, Fall 2013, 851 out of 1100 students enrolled in the classic version of the course and 184 out of 240 enrolled in the revised version of the course consented to participate. For the fall 2014 semester, of 1400 total, 1161 (at the beginning of the semester) and 1065 (at the end of the semester) completed the survey and consented to participate in the study.
\end{abstract}

Specifically, we address the following research questions:

1) How did first year students' identity, utility, belonging, and expectancy motivation constructs change during the course of the first year?

2) How do these constructs differ between students in the 'classic' and revised course?

The findings should be useful to programs changing, or anticipating changes to their first-year programs.

Index Terms - Motivation, curriculum revision, first year, FYE changes.

\section{Introduction}

One of the primary goals of undergraduate engineering education programs is to enhance the retention of engineering students. Research has shown that predicting retention in engineering is best done by examining a mix of students' cognitive and affective or motivational characteristics. Prior research has shown that many of these affective characteristics decrease specially over the first year in engineering, which is certainly not a desirable trend ${ }^{1,2}$. Specifically, a study involving one cohort of first-year engineering students from a large public university showed that first-year engineering students' expectancy-related beliefs, including expectations for success in engineering and self-efficacy in engineering, as well as value related beliefs, including identification with engineering, interest, cost, and utility value decreased over their first year for both male and female students. Within this population, male students reported a higher level of expectation for success than female students; higher expectation for success tended to predict a higher academic performance over the first year ${ }^{3}$.

Engineering programs have seen a wave of revisions in their first-year programs in recent years, often with a goal to build community among students, which should improve, or at least mitigate, negative changes in affective characteristics. This university revised its first-year engineering program to eliminate a large lecture, move toward a workshop model, and introduce a curriculum that is more project-based, among other changes, with a goal of more effectively supporting student motivation to 
enhance retention. Sections of the 'classic' and revised courses were offered in one semester for the same cohort of students. Data on motivation constructs such as identity, utility, belonging, and expectancy was collected early in the first semester, after the first semester and near the end of the first year for students in both introductory courses.

This research paper will describe the course modification and prior research which forms a baseline for the study of changes in motivational constructs as students progress through the introductory engineering sequence. We address the following research questions, focusing on motivation:

1) How did first year students' identity, utility, belonging, and expectancy motivation constructs change during the course of the first year?, and

2) How do these constructs differ between students in the 'classic' and revised course?

The findings should be useful to programs changing, or anticipating changes to their first-year programs.

\section{Background of the work}

Our study is situated in motivation theories of learning. Motivation has been defined as "the extent to which one intends to engage in an activity"4. The choice or the decision to continue doing an activity, for example, is the result of someone's motivation of doing that activity. Motivation has been explored in relation to academic performance and career plans. Jones et al. studied the relationship among expectancies, values, achievement, and career plans for first year engineering students. They found that students' expectancy and value related beliefs decreased over the first year ${ }^{3}$ thus negatively influencing students' retention into the second year of an engineering program. Predicting students' intention to continue within engineering is complex, and the factors associated to this decision are not well understood; however motivational constructs are theorized to play an important role in studies of retention and success.

In our study, we analyze motivational constructs included in a survey as part of the assessment of first year engineering courses. The motivational constructs included in this survey are:

1) Identity, the extent to which one defines the self through a role or performance in engineering;

2) Utility, the usefulness of engineering in terms of reaching one's short and long-term goals;

3) Belonging, perception of inclusion in the community; and

4) Expectancy, one's belief in the possibility of his or her success in engineering.

By understanding how students' motivation changes over the first year we aim to inform the curricular development of the first year engineering introductory courses with a goal of increasing students' motivation, among others, thus improving learning and retention.

\section{The Course}

All engineering students at this university enter into a general, interdisciplinary engineering program and select specific disciplines after their first year, as is the case at many universities. There is a twosemester required Foundations of Engineering course sequence; the first course was more focused on design while the second course was more focused on engineering computation. The courses share content which is integrated over both semesters. The courses were significantly revised prior to the 2013-14 academic year. 
The revised version of the courses moved from a large lecture and lab format to a project-based, workshop model with an average of 30 students per section. The curriculum was significantly revised and purposefully designed to include topics such as working with real time data acquisition, modeling systems, and designing products and systems. Curriculum encouraging students to explore their areas of interest was included; attendance at an exposition to students of the diversity engineering fields and majors was required. Activities and a project with an emphasis on engineering problem solving skills were incorporated. The curricular changes were based on an exploration of the literature, research, and expertise of faculty and instructors of the course. This paper will discuss initial analysis of the motivation assessment based on the survey results.

\section{Survey Instrument}

To assess the impact of the revised version of the course on students motivation, a survey was administered to all first year engineering students at the beginning and at the end of the first semester in both versions, classic and revised, for the same cohort of students. The same survey was administered and analyzed for the second time the revised version of the course was offered (the first full-scale implementation of the course), no classic version of the course was offered that semester. This survey had been developed and validated in prior work ${ }^{3}$. The instrument consists of 23 questions assessing motivation (along with other questions to collect demographic and course specific data). Students were asked to rate their level of agreement with each statement by using a 6 points Likert-type scale $(1=$ strongly disagree; $6=$ strongly agree).

For the purpose of this study, we will compare students enrolled in the classic version of the course and students enrolled in the revised version. Note that placement of students into either version of the course is completely random.

\section{Participants}

Consenting students - 851 of a possible 1100 students enrolled in the classic version of the course, and 184 of 240 students enrolled in the revised version of the course during Fall 2013 - agreed to participate in the study. The revised course was offered a second time in Fall 2014; 1161 of 1400 students enrolled completed the survey and consented to participate in the study. Approximately $24 \%$ of the participants were female and $32 \%$ were underrepresented minorities (URM).

As part of data preparation, participants for which data existed for complete constructs were included, even if they did not complete the survey ${ }^{5}$. For example, some students did not complete the entire survey but fulfilled all questions within one construct of motivation; these students were considered in the analysis for that construct (we found only two such cases in the entire dataset). In addition, where duplicates entries were found, the second student entry was deleted, keeping 1) the first attempt, for the beginning of the semester survey and 2) the last attempt for the end of the semester survey, as long as these attempts were complete.

\section{Results}

Descriptive statistics were used to analyze the survey instrument in a number of different ways. Cronbach's alpha was used as a measure of internal consistency of scales (See Table 1). As Cronbach's 
coefficient alpha is sensitive to sample size, the Spearman-Brown formula was used to estimate Cronbach's alpha for constructs containing less than 10 items $^{6}$. All constructs had acceptable reliability (>0.7) with the exception of the belonging construct in the beginning of the semester Fall 2014 survey which had 0.668; however this coefficient value can be considered acceptable, given the small number of questions per construct ${ }^{7}$.

Table 1. Motivational constructs, corresponding number of items and internal reliability coefficient for each course. [Note: BOS = beginning of semester: EOS = end of semester]

\begin{tabular}{|c|c|c|c|}
\hline Construct & $\mathrm{N}$ of Items & Conbrach's Alpha & Course Type \\
\hline \multirow[t]{6}{*}{ Identity } & \multirow[t]{6}{*}{4} & 0.756 & BOS Classic Fall 2013 \\
\hline & & 0.819 & EOS Classic Fall 2013 \\
\hline & & 0.819 & BOS FYE Fall 2013 \\
\hline & & 0.841 & EOS FYE Fall 2013 \\
\hline & & 0.724 & BOS FYE Fall 2014 \\
\hline & & 0.778 & EOS FYE Fall 2014 \\
\hline \multirow[t]{6}{*}{ Utility } & \multirow[t]{6}{*}{6} & 0.879 & BOS Classic Fall 2013 \\
\hline & & 0.941 & EOS Classic Fall 2013 \\
\hline & & 0.913 & BOS FYE Fall 2013 \\
\hline & & 0.959 & EOS FYE Fall 2013 \\
\hline & & 0.884 & BOS FYE Fall 2014 \\
\hline & & 0.932 & EOS FYE Fall 2014 \\
\hline \multirow[t]{6}{*}{ Belonging } & \multirow[t]{6}{*}{8} & 0.753 & BOS Classic Fall 2013 \\
\hline & & 0.832 & EOS Classic Fall 2013 \\
\hline & & 0.821 & BOS FYE Fall 2013 \\
\hline & & 0.824 & EOS FYE Fall 2013 \\
\hline & & 0.668 & BOS FYE Fall 2014 \\
\hline & & 0.816 & EOS FYE Fall 2014 \\
\hline \multirow[t]{6}{*}{ Expectancy } & \multirow[t]{6}{*}{5} & 0.853 & BOS Classic Fall 2013 \\
\hline & & 0.891 & EOS Classic Fall 2013 \\
\hline & & 0.807 & BOS FYE Fall 2013 \\
\hline & & 0.900 & EOS FYE Fall 2013 \\
\hline & & 0.816 & BOS FYE Fall 2014 \\
\hline & & 0.901 & EOS FYE Fall 2014 \\
\hline
\end{tabular}


To examine the possible differences between the two groups of students taking the courses during the same semester, we conducted independent t-tests to compare the values of the means of the groups in the new version and the classic version of the course. Because the data was not normally distributed, Wilcoxon tests were conducted. Results of the independent $t$-tests, when the revised version of the course was offered the first time (Fall 2013), are presented in the Tables 2 and 3, p-values less than 0.05 are considered significant. Effect sizes were also calculated to demonstrate the 'importance' of any differences since statistical significance can be affected by larger sample sizes. According to Cohen a correlation of 0.8 is large, 0.5 is moderate, and 0.2 is small ${ }^{8}$.

Table 2. Comparison of motivational constructs at the beginning of the first semester of the revised course implementation (Fall 2013).

\begin{tabular}{|c|c|c|c|c|c|}
\hline $\begin{array}{l}\text { Population } \\
\text { (Course) }\end{array}$ & $\mathbf{N}$ & Construct & Mean (SD) & $\begin{array}{l}\text { P-value } \\
\text { (2-tailed) }\end{array}$ & $\begin{array}{l}\text { Effect Size } \\
\text { (Cohen's d) }\end{array}$ \\
\hline $\begin{array}{c}\text { Classic BOS Fall } \\
2013\end{array}$ & 851 & \multirow[t]{2}{*}{ Identity } & $5.2497(0.6545)$ & \multirow[t]{2}{*}{0.379} & \multirow[t]{2}{*}{0.067} \\
\hline $\begin{array}{l}\text { FYE BOS Fall } \\
2013\end{array}$ & 184 & & $5.2052(0.6583)$ & & \\
\hline $\begin{array}{c}\text { Classic BOS Fall } \\
2013\end{array}$ & 851 & \multirow[t]{2}{*}{ Utility } & $5.4877(0.6728)$ & \multirow[t]{2}{*}{0.098} & \multirow[t]{2}{*}{0.1876} \\
\hline $\begin{array}{l}\text { FYE BOS Fall } \\
2013\end{array}$ & 184 & & $5.3379(0.9059)$ & & \\
\hline $\begin{array}{c}\text { Classic BOS Fall } \\
2013\end{array}$ & 851 & \multirow[t]{2}{*}{ Belonging } & $4.9768(0.6217)$ & \multirow[t]{2}{*}{0.556} & \multirow[t]{2}{*}{0.042} \\
\hline $\begin{array}{l}\text { FYE BOS Fall } \\
2013\end{array}$ & 183 & & $4.9501(0.6330)$ & & \\
\hline $\begin{array}{c}\text { Classic BOS Fall } \\
2013\end{array}$ & 851 & \multirow[t]{2}{*}{ Expectancy } & $4.8421(0.6825)$ & \multirow[t]{2}{*}{0.131} & \multirow[t]{2}{*}{0.113} \\
\hline $\begin{array}{l}\text { FYE BOS Fall } \\
2013\end{array}$ & 183 & & $4.9180(0.6513)$ & & \\
\hline
\end{tabular}


Table 3. Comparison of motivational constructs at the end of the first semester of the revised course implementation (Fall 2013).

\begin{tabular}{|c|c|c|c|c|c|}
\hline $\begin{array}{l}\text { Population } \\
\text { (Course) }\end{array}$ & $\mathbf{N}$ & Construct & $M(S D)$ & $\begin{array}{l}\text { P-value } \\
\text { (2-tailed) }\end{array}$ & Effect Size \\
\hline $\begin{array}{c}\text { Classic EOS Fall } \\
2013\end{array}$ & 810 & \multirow[t]{2}{*}{ Identity } & $5.1929(0.7375)$ & 0.464 & 0.042 \\
\hline $\begin{array}{l}\text { FYE EOS Fall } \\
2013\end{array}$ & 240 & & $5.2240(0.7390)$ & & \\
\hline $\begin{array}{c}\text { Classic EOS Fall } \\
2013\end{array}$ & 810 & \multirow[t]{2}{*}{ Utility } & $5.2749(0.9607)$ & 0.900 & 0.031 \\
\hline $\begin{array}{l}\text { FYE EOS Fall } \\
2013\end{array}$ & 240 & & $5.2431(1.0835)$ & & \\
\hline $\begin{array}{c}\text { Classic EOS Fall } \\
2013\end{array}$ & 809 & \multirow[t]{2}{*}{ Belonging } & $4.7407(0.6710)$ & 0.302 & 0.065 \\
\hline $\begin{array}{l}\text { FYE EOS Fall } \\
2013\end{array}$ & 240 & & $4.7844(0.6662)$ & & \\
\hline $\begin{array}{c}\text { Classic EOS Fall } \\
2013\end{array}$ & 809 & \multirow[t]{2}{*}{ Expectancy } & $4.7125(0.7724)$ & 0.071 & 0.151 \\
\hline $\begin{array}{l}\text { FYE EOS Fall } \\
2013\end{array}$ & 240 & & $4.8225(0.6764)$ & & \\
\hline
\end{tabular}

In general there was no significant difference in the motivational constructs between the two versions of the course in the semester where the revised course was implemented the first time (the pilot offering).

In addition to comparing the classic and revised versions of the course at the beginning and end of the first semester, we compared changes in students' motivation in the Fall 2014 semester when a more mature version of the revised course was offered - the first offering of the course beyond the pilot. Table 4 and 5 show the results of the independent t-test when we compared the classic version of the course with the more mature revised version the course was offered. 
Table 4. Comparison of motivational constructs at beginning of the second semester of the revised course implementation.

\begin{tabular}{|c|c|c|c|c|c|}
\hline $\begin{array}{l}\text { Population } \\
\text { (Course) }\end{array}$ & $N$ & Construct & $M(S D)$ & $\begin{array}{l}\text { P-value } \\
\text { (2-tailed) }\end{array}$ & Effect Size \\
\hline $\begin{array}{c}\text { Classic BOS Fall } \\
2013\end{array}$ & 851 & \multirow[t]{2}{*}{ Identity } & $5.2497(0.6545)$ & 0.788 & 0.032 \\
\hline $\begin{array}{l}\text { FYE BOS Fall } \\
2014\end{array}$ & 1161 & & $5.2698(0.5991)$ & & \\
\hline $\begin{array}{c}\text { Classic BOS Fall } \\
2013\end{array}$ & 851 & \multirow[t]{2}{*}{ Utility } & $5.4877(0.6728)$ & 0.471 & 0.028 \\
\hline $\begin{array}{l}\text { FYE BOS Fall } \\
2014\end{array}$ & 1161 & & $5.5069(0.6640)$ & & \\
\hline $\begin{array}{c}\text { Classic BOS Fall } \\
2013\end{array}$ & 851 & \multirow[t]{2}{*}{ Belonging } & $4.9768(0.6217)$ & 0.693 & 0.002 \\
\hline $\begin{array}{l}\text { FYE BOS Fall } \\
2014\end{array}$ & 1161 & & $4.9751(0.5322)$ & & \\
\hline $\begin{array}{c}\text { Classic BOS Fall } \\
2013\end{array}$ & 851 & \multirow[t]{2}{*}{ Expectancy } & $4.8421(0.6825)$ & 0.866 & 0.020 \\
\hline $\begin{array}{c}\text { FYE BOS Fall } \\
2014\end{array}$ & 1161 & & $4.8556(0.6527)$ & & \\
\hline
\end{tabular}

Table 5. Comparison of motivational constructs at the end of the second semester of the revised course implementation.

\begin{tabular}{|c|c|c|c|c|c|}
\hline $\begin{array}{c}\text { Population } \\
\text { (Course) }\end{array}$ & $N$ & Construct & $M(S D)$ & $\begin{array}{c}\text { P-value } \\
\text { (2-tailed) }\end{array}$ & Effect Size \\
\hline $\begin{array}{c}\text { Classic EOS Fall } \\
2013\end{array}$ & 810 & \multirow[t]{2}{*}{ Identity } & $5.1929(0.7375)$ & $0.038^{*}$ & 0.096 \\
\hline $\begin{array}{c}\text { FYE EOS Fall } \\
2014\end{array}$ & 1065 & & $5.2627(0.7070)$ & & \\
\hline $\begin{array}{c}\text { Classic EOS Fall } \\
2013\end{array}$ & 810 & \multirow[t]{2}{*}{ Utility } & $5.2749(0.9607)$ & $0.013^{*}$ & 0.115 \\
\hline $\begin{array}{c}\text { FYE EOS Fall } \\
2014\end{array}$ & 1065 & & $5.3820(0.8870)$ & & \\
\hline $\begin{array}{c}\text { Classic EOS Fall } \\
2013\end{array}$ & 809 & \multirow[t]{2}{*}{ Belonging } & $4.7407(0.6710)$ & 0.333 & 0.046 \\
\hline $\begin{array}{c}\text { FYE EOS Fall } \\
2014\end{array}$ & 1065 & & $4.7721(0.6722)$ & & \\
\hline $\begin{array}{c}\text { Classic EOS Fall } \\
2013\end{array}$ & 809 & \multirow[t]{2}{*}{ Expectancy } & $4.7125(0.7724)$ & $0.001 *$ & 0.1541 \\
\hline $\begin{array}{c}\text { FYE EOS Fall } \\
2014\end{array}$ & 1065 & & $4.8317(0.7740)$ & & \\
\hline
\end{tabular}

$* \mathrm{p}<0.05$

As expected, since the placement of students into either version of the course is completely random, at the beginning of the semester, we did not find any statistically significant difference between the two versions of the course (See Table 4). Table 5 shows the results when we compared the two versions of the course, Classic Fall 2013 (the original course before revision) and FYE Fall 2014 (the revised, project-based course on its first offering beyond the pilot), at the end of the semester. Statistically significant differences were found in Identity, Utility, and Expectancy constructs 
In addition, paired t-tests were also used to compare the values of means from students within the same course. Table 6 and 7 show the results of the paired t-test comparing means at the beginning and at the end of the semester in the classic and the revised versions of the course respectively

Table 6. Comparison of motivational constructs beginning vs the end of the "classic" version of the course.

\begin{tabular}{|c|c|c|c|c|c|}
\hline $\begin{array}{l}\text { Population } \\
\text { (Course) }\end{array}$ & $\mathbf{N}$ & Construct & $M(S D)$ & $\begin{array}{l}\text { P-value } \\
\text { (2-tailed) }\end{array}$ & Effect Size \\
\hline $\begin{array}{c}\text { BOS Classic Fall } \\
2013\end{array}$ & 796 & \multirow[t]{2}{*}{ Identity } & $5.2494(0.6525)$ & $0.016 *$ & 0.097 \\
\hline $\begin{array}{c}\text { EOS Classic Fall } \\
2013\end{array}$ & 796 & & $5.1793(0.7838)$ & & \\
\hline $\begin{array}{c}\text { BOS Classic Fall } \\
2013\end{array}$ & 796 & \multirow[t]{2}{*}{ Utility } & $5.5017(0.6427)$ & $<0.001^{*}$ & 0.274 \\
\hline $\begin{array}{l}\text { EOS Classic Fall } \\
2013\end{array}$ & 796 & & $5.2766(0.9631)$ & & \\
\hline $\begin{array}{c}\text { BOS Classic Fall } \\
2013\end{array}$ & 796 & \multirow[t]{2}{*}{ Belonging } & $4.9818(0.6211)$ & $<0.001^{*}$ & 0.383 \\
\hline $\begin{array}{c}\text { EOS Classic Fall } \\
2013\end{array}$ & 796 & & $4.7312(0.6831)$ & & \\
\hline $\begin{array}{c}\text { BOS Classic Fall } \\
2013\end{array}$ & 796 & \multirow[t]{2}{*}{ Expectancy } & 4.8394 (0.6719) & $<0.001^{*}$ & 0.186 \\
\hline $\begin{array}{c}\text { EOS Classic Fall } \\
2013\end{array}$ & 796 & & $4.6990(0.8238)$ & & \\
\hline
\end{tabular}

$$
* \mathrm{p}<0.05
$$

Table 7. Comparison of motivational constructs beginning vs the end of the revised version of the course the first time this version was offered (pilot).

\begin{tabular}{|c|c|c|c|c|c|}
\hline $\begin{array}{c}\text { Population } \\
\text { (Course) }\end{array}$ & $\mathbf{N}$ & Construct & $M(S D)$ & $\begin{array}{l}\text { P-value } \\
\text { (2-tailed) }\end{array}$ & Effect Size \\
\hline $\begin{array}{l}\text { BOS FYE Fall } \\
2013\end{array}$ & 168 & \multirow[t]{2}{*}{ Identity } & $5.1756(0.6693)$ & 0.233 & 0.092 \\
\hline $\begin{array}{c}\text { EOS FYE Fall } \\
2013\end{array}$ & 168 & & $5.2411(0.7396)$ & & \\
\hline $\begin{array}{c}\text { BOS FYE Fall } \\
2013\end{array}$ & 168 & \multirow[t]{2}{*}{ Utility } & $5.3046(0.9341)$ & 0.681 & 0.057 \\
\hline $\begin{array}{l}\text { EOS FYE Fall } \\
2013\end{array}$ & 168 & & $5.2460(1.0848)$ & & \\
\hline $\begin{array}{l}\text { BOS FYE Fall } \\
2013\end{array}$ & 167 & \multirow[t]{2}{*}{ Belonging } & $4.9319(0.6285)$ & $<0.001 *$ & 0.265 \\
\hline $\begin{array}{c}\text { EOS FYE Fall } \\
2013\end{array}$ & 167 & & $4.7537(0.7131)$ & & \\
\hline $\begin{array}{l}\text { BOS FYE Fall } \\
2013\end{array}$ & 167 & \multirow[t]{2}{*}{ Expectancy } & $4.8982(0.6418)$ & 0.125 & 0.121 \\
\hline $\begin{array}{c}\text { EOS FYE Fall } \\
2013\end{array}$ & 167 & & $4.8180(0.6958)$ & & \\
\hline
\end{tabular}

$$
* \mathrm{p}<0.05
$$


In the classic version of the course, all the four constructs resulted statistically lower at the end of the semester whereas in the revised version of the course only one construct, belonging, resulted significantly lower at the end of the semester.

\section{Analysis}

To compare the changes in the motivational constructs in the two version of the courses, we first compared data from the same semester where both courses were offered (Fall 2013) - the original and the pilot of the revised course; after this, we compared the classic version (Fall 2013) with a more mature version of the revised course the second time it was offered (Fall 2014) using independent t-tests in all the cases.

In general, there is no significant difference in the motivational constructs between the two versions of the course when the revised course was implemented the first time (Tables 2 and 3); however, when we compared the classic version of the course (Fall 2013) with the more mature revised version ( Fall 2014) (Table 4 and 5), we found that the means for Identity, Utility and Expectancy motivational constructs increased and presented a slightly significant difference at the end of the semester (Cohen's $\mathrm{d}=0.096$, 0.015 , and 0.1541 respectively).

Identity refers to the extent to which one defines the self through a role or performance in engineering (Classic Fall 2013: $M=5.19, \mathrm{SD}=0.73$ and FYE Fall 2014: $\mathrm{M}=5.26, \mathrm{SD}=0.70$ ). The difference at the end of the semester between the Classic version in Fall 2013 and the revised version in Fall 2014 was statistically significant, this finding might suggest that students in the revised version developed slightly higher level of identity as engineers. Utility refers to the usefulness of engineering in terms of reaching one's short and long-term goals (Classic Fall 2013: M=5.27, SD=0.96 and FYE Fall 2014: M= 5.38, $\mathrm{SD}=0.88$ ). Similarly to the results for the Identity construct, the difference at the end of the semester between the Classic version in Fall 2013 and the revised version in Fall 2014 was statistically significant, this suggests that students in the revised course had a higher perception of why the course content was useful for their short or long term goals. Belonging refers to the perception of inclusion in the community (Classic Fall 2013: $M=4.74, S D=0.67$ and FYE Fall 2014: $M=4.77, S D=0.67$ ), this construct did not present statistically significant difference between the two versions of the course. Finally, Expectancy refers to the student's belief of their success in engineering (Classic Fall 2013: $\mathrm{M}=4.71, \mathrm{SD}=0.77$ and FYE Fall 2014: $\mathrm{M}=4.83, \mathrm{SD}=0.77$ ). Similarly to Identity and Utility constructs, the difference at the end of the semester between the Classic version in Fall 2013 and the revised version in Fall 2014 was statistically significant, this suggests that students in the revised version of the course had a higher perception of success in the course. Student perceptions of their likely success can affect their engagement in the class ${ }^{4}$.

Further, we compared data from the beginning and the end of the semester for each version of the course using paired t-test. The results of this analysis are shown in tables 6 and 7. In the classic version of the course, the four motivational constructs: Identity, Utility, Belonging, and Expectancy were found to have changed significantly; however, the effect sizes for these changes are considered small (Cohen's $\mathrm{d}=0.097,0.274,0.383$, and 0.186 respectively). These small effect sizes suggests that, even in the event of a statistically significant difference among construct values, the importance of the significance is small. In other words, the significance may be enhanced by a large sample size. Overall, our identification of differences in motivational constructs between the beginning and the end of the semester in both courses replicates findings from prior studies that indicate that students' motivation decreases over the first year in an engineering program. In the revised version of the course, of the four 
constructs, only Belonging was significantly lower at the end of the semester (Cohen's $d=0.265)$. It is worth noting, however, that the other three motivational constructs did not change significantly.

\section{Conclusions and Future Work}

This study, in its initial stage, sought to examine the possible differences and changes in constructs within motivation for first year students during the revision of a first year curriculum. Results of the surveys can be applied in foundational courses to reveal critical information about students' motivation, attitudes, and beliefs about engineering and their intention to completing an engineering degree. Although the motivational constructs did not present statistically significant differences between the two versions of the course, our identification of differences in motivational constructs between the beginning and the end of the semester in both courses replicates findings from prior studies that indicate that students' motivation decreases over the first year in an engineering program. The finding that the more mature offering of the revised course seems to mitigate drops in constructs associated with motivation is promising.

The most interesting finding of this study is that when the revised version of the course was taught for the second time we found statistically significant difference in Identity, Utility and Expectancy motivational constructs between the two versions of the course. Additional research is needed to measure changes in students' motivation in the following semesters when the new, mature version of the course has been offered. Further analysis is planned to compare the pilot version of the refined course with subsequent offering to assess whether the population of the pilot course is representative of the entire population of first-year engineering students.

We recognize a limitation that the two versions of the course are not the only difference that can affect students' motivation; instructors, for example, play a major role in motivating students by creating and fostering effective learning environments in the classroom, we had different instructors in the courses we compared. Another limitation of our work is that the survey is applied only at two points during the semester, at the beginning and at the end; intermediate surveys could give more information about trajectories in students' beliefs along the semester. In the same way, qualitative research could be beneficial since our data is reduced to numbers, therefore, students' voices about their own motivation may not be adequately represented and could help to better understand the revision needed in the curriculum and instruction.

\section{REFERENCES}

1. Reid, K. J., (2009). Development of the Student Attitudinal Success Instrument: Assessment of first year engineering students including differences by gender (Doctoral dissertation). Available from ProQuest Dissertations and Theses database. (AAI 3378850)

2. Reid, K. \& Imbrie, P.K. (2008). Noncognitive characteristics of incoming engineering students compared to incoming engineering technology students: A preliminary examination. Proceedings of the American Society for Engineering Education National Conference, Pittsburgh, PA.

3. Jones, B. D., Paretti, M. C., Hein, S. F., \& Knott, T. W. (2010). An Analysis of Motivation Constructs with First-Year Engineering Students: Relationships Among Expectancies, Values, Achievement, and Career Plans. Journal of Engineering Education, 99(4), 319-336.

4. Jones, B. D. (2015). Motivating Students by Design: Practical Strategies for Professors: CreateSpace Independent Publishing Platform. 
5. Creswell, J. W. (2012). Educational research : planning, conducting, and evaluating quantitative and qualitative research. Boston: Pearson.

6. Alsawalmeh, Y. M., \& Feldt, L. S. (1999). Testing the Equality of Two Independent $\alpha$ Coefficients Adjusted by the Spearman-Brown Formula. Applied Psychological Measurement, 23(4), 363-370. doi:10.1177/01466216990234006

7. Tavakol, M., \& Dennick, R. (2011). Making sense of Cronbach's alpha. International Journal of Medical Education, 2, 53-55. doi:10.5116/ijme.4dfb.8dfd

8. Cohen, J. (1988). Statistical power analysis for the behavioral sciences. Hillsdale, N.J.: L. Erlbaum Associates. 